\title{
Covid-19, Socio-Economic Impact and the Nigerian Government: An Overview
}

\section{Chukwudi EC ${ }^{1}$ and Idowu SS ${ }^{2 *}$}

${ }^{1}$ Department of Political Science and International Relations, Caleb University, Nigeria

${ }^{2}$ Department of Political Science and International Relations, Caleb University, Nigeria

*Corresponding author: Samuel Sunday Idowu, Department of Political Science and International Relations, Caleb University, Ota, Ogun State, Nigeria, Email: Samuel.idowu@ calebuniversity.edu.ng

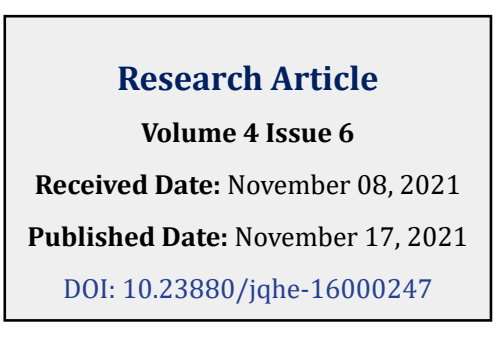

DOI: $10.23880 /$ jqhe-16000247

\section{Abstract}

The outbreak of Covid-19 has both local and global implications with the response at both levels. However, national governments are the major player and device strategy and measures to lessen the negative impact on their populace. This paper carried out an overview of the Nigerian case with emphasis on the social and economic sides vis-à-vis government palliatives response measures. The analytical design was used to critically examine secondary data while the social contract theory was employed as a framework. The findings reveal that the Nigerian government efforts to lessen the adverse effects of the pandemic produced minimal impact due to government unpreparedness, corruption and administrative laxity. It recommends that the Nigerian governments should scale up their level of preparation for emergency situations and ramp up investment in the health sector for better performance amongst others.

Keywords: Covid-19; Economic; Impact; Nigeria; Palliatives; Social

\section{Introduction}

The Coronavirus disease pandemic, though not the first, but appears as the most deadly, and has all-around monumental adverse effects on virtually all countries of the world, with huge disruption of the national and the transnational global socio-economic landscape. The World Health Organization (WHO) [1] described the Coronavirus disease, christened COVID-19, as a highly contagious disease caused by Severe Acute Respiratory Syndrome -SARS-CoV-2 Virus. It seems to occupy a class of its own in the annals of the SARS virus group, making it distinct and unprecedented. Though controversial narratives surround the cause of Covid-19 there is unanimity of opinion that it was first seen or originated from Wuhan city of Hubei Province China in December 2019 and Hafeez, at al. [2]contend that it is connected with the Husband Seafood market (South China) where dogs, bats, snakes and other animals. The fast- spreading feature of the virus not only hastens its popularity but also news about it frightening and fretful to the global community which, according to WHO [1], can extend from someone that is already exposed to the disease through mouth or nose especially when they are with activities like coughing, speaking, sneezing, singing or breathing.

On 27th February 2020, the Nigeria Federal Ministry of Health announced the confirmation of the first case of Coronavirus infection in Lagos State [3]. This ignites the wave of apprehension for the disease and the perceptible accompanying negative aftermath in the developing country housing the largest population in the Africa continent as well as the economic profile aptly captured thus:

Nigeria has the biggest economy in Africa, with a gross domestic product per capita of $\$ 2,028$ in 2018 , more than twice that of its neighbors Benin, Chad, or Niger. It is also a 
highly unequal country. In 2010, the Gini coefficient of income per capita that is used to measure inequality was 49 , notably above the international alert line of 40 that warns about the negative social, economic, and political consequences. Economic data suggest that levels of inequality have not improved since [4].

While the WHO [1] informed that the perfect way to keep Covid-19 from spreading is to get proper information about it, protect oneself, and others through ensuring a distance of 1 meter from others, frequent washing of hands and vaccination, Nigerians seems to be apathetic to this new way of life and vocabulary and likewise skeptical to the national and sub-national government capacity for managing the attending challenges such that would minimize the adverse impact on the populace hinging their fear on the pre-pandemic poor governance indicators and experience, especially in regard to the social and economic measurement of livelihood. Therefore, can one argue that the Nigerian governments tackle the socio-economic problems associated with the Covid-19 pandemic frontally? .

Although most countries put in place different measures to combat the spread of Covid-19, Nigeria with its position as the economic giant of Africa has greater role to play because of its huge population. The World Bank [5] confirmed and described Nigeria as a country that plays great roles in West Africa with an approximate population of 202 million and blessed with large natural resources maintaining the position of the biggest oil exporter in Africa and largest population of youth in the world. As such, the Nigeria government seems to require extra effort to protect its citizens from the ravaging covid-19 and its consequences just like other countries, developed and developing, and possibly rendering assistance to the latter that are worst hit.

However, to what extent did the government deploy machinery and resources for this purpose? This becomes more problematic, disturbing and demands in-depth examination as the UNHCR [6] observes that the measures put in place by the Nigerian government towards slowing the spread of the deadly virus negatively affected the survival of the people making many to experienced economic disappointment while Dixit, et al. [7] maintains also that governments health, social and economic measures have embedded in their weaknesses. This paper objective, therefore, is to probe the Nigerian governments (national and sub-national) efforts impact on the populace in ameliorating the social and economic hardship that accompanied the outbreak of the Covid-19 pandemic. The article is divided into six sections which are: the introduction, theoretical framework, methodology, Covid-19 and Nigeria Soci0economic sector, overview of governments' palliative measures and conclusion and recommendations.

\section{Theoretical Framework}

The social contract theory is employed to underpin this paper. The theory origin is traced to Thomas Hobbes (15881679) who portray a natural state of man characterized by a war-like situation or contest for food and other material, making life poor brutish, nasty and short and necessitate contractual agreement for safety and wellbeing [8]. Though Locke (1632-1704) disputed the natural state of Hobbes and posits that it is a state of absolute freedom, they both concede to having an organized society where governance is pursued to the benefit of the people. Put differently, the agreement is reached in the society by the people to surrender part of their right to the sovereign authority for security and socioeconomic welfare. In this sense, the government is to ensure that the citizens' natural rights are protected and satisfied within and without.

This is applicable to this paper because the Nigerian governments at all levels are constitutionally constituted which is a typical form of a social contract and a veritable means of legitimacy. However, the functionality of the agreement can be ascertained when the peoples' security and welfare are promptly and adequately served, especially amidst danger or emergency such as the Covid-19 pandemic. Is this the masses experience in Nigeria?.

\section{Methodology}

The analytical research method is adopted for this paper. Data from secondary sources are engaged to critically analyze the subjects and issues addressed by the research as ample information is available in Newspapers, Magazines, Journals and impeccable online outlets. And, because the pandemic is a current problem, the data is also recent which make their sources reliable and valid.

\section{Covid-19 and Nigeria Socio-Economic Sectors}

The Covid-19 pandemic has had and still makes a calamitous impact on the socio-economic sectors across national boundaries. The country lockdown and the restrictions that followed the discovery of Covid-19 in Nigeria turned many lives, businesses and sectors around for the least expected downturn. Though the social and economic sectors are wide in scope this article concerns itself with the prominent ones to elicit the associated effect of Covid-19 on them.

\section{Religious Institutions}

The shutdown of worship centers as part of measures to curtail the spread of the Covid-19 is not peculiar to Nigeria but cross-national. However, the response of religious 
denominations or institutions to ban on congregational gatherings for about six months in Nigeria seems to vary as some complied while others resisted. Meanwhile, the Nigerian government deployed machinery to enforce this rule or ensure compliance but appears to share an experience reported in the United States and some African countries where according to Yhdego, et al. [9] a Christian Preacher of a megachurch was picked up for violating Covid-19 rules as he continually held church services at the time of US quarantine and many African Pentecostal Christians placed Coronavirus as a "spiritual force of evil" instead of portraying it as a biomedical disease respectively. This implies that the religious leaders are averse not only to the worship disruption but also its income, social and psychological effect these tend to have on them and followers; and look up to the governments for assistance.

As an alternative to physical meetings and compliance measures, the Christian Association of Nigeria (CAN), the umbrella covering all Christian denominations, persuades churches to adopt online services as part of the efforts to contain the spread of the virus. For instance, the Catholic Bishop of Enugu Diocese, Most Rev. Callistus Onaga, representing church leaders posited that they maintain their promise to carry out government directives on covid-19 rules [10]. Therefore, information and communication technology (ICT) was deployed to achieve this purpose heightening the cost of purchase and service amidst lowerincome challenges experienced by both the worshippers and religious leaders due to grounded of commercial activities in response to the pandemic. Also, religious institutions could not continue their projects, run their schools or care for the needy [9]. Implicitly, faith-based contributions to social development were seriously disrupted aside from nonphysical connection, where possible, for meeting or worship.

Nevertheless, Nigerians await the government, especially the central, to include internet subsidy as part of the palliative measures to cushion the effects of the flourishing online presence, not only for business activities but worship as well. However, this was not the case but rather a somewhat increase in the cost was witnessed alongside poor network service by the internet service providers. In this case, the religious community seems unsatisfied with the government handling of the crisis and often expresses their displeasure in diverse ways such as reaching out to the proselytes and community with relief materials in form of material or cash donation.

There appears to be a contrasting situation as the government across all levels believes that religious leaders and organizations are critical to slowing the curve of the covid-19 while failing to motivate the same by giving the expected support. To improve this situation, TBIGC [11] submits that the national and the local religious leaders have organizational capabilities and advised that government should develop trust with Faith Based Organizations (FBO) and bring them into planning, taking decision and the execution of the Covid-19 response at every stage.

It is apparent that the principle of 'give-and-take' is violated by governments and its consequences on united efforts to mitigate the pandemic cannot be undermined. To lessen the impact of the failure on the society and the pandemic management in the post-lockdown period, the Nigerian governments need to boost its cooperation with the religious groups especially, in ensuring an effective vaccination against the covid-19 which, according to ChurchHill, et al. [12], is important for the government to deploy religion organizations as channels to reach larger population especially on Sundays for Christians and Fridays for Muslims if the immunization exercise is to record a quantum success. Moreover, the institution is as well needed to intensify the campaign to discourage vaccination apathy or rejection occasioned by the 'conspiracy theory' which seems to be gaining more popularity in the country.

\section{Educational Institutions}

Education as a sector has its original challenge in Nigeria as a developing country. While Anyika, et al. [13] stressed the problem that bedeviled the educational system before now as limited funds, inadequate and dilapidating infrastructure, inadequate teaching facilities, poor teachers' welfare, poor research funding, and poor quality of teachers, the situation seems to have aggravated in the covid-19 era. These began with the closure of all schools in Nigeria by the Federal Government On March $19^{\text {th }} 2020$ for a month because of the dreaded covid-19 [3]. But because the closure was extended beyond the initial one month, schools resorted to an online learning systems, creating new challenges of facility, skill and infrastructure for schools, teachers and learners. Furthermore, not only that most schools lack internet facilities did not train teachers and students, suffer underfunding, they likewise were caught unprepared for the necessary or compelling off-site learning situation.

It is noteworthy that in response to the occasion, the Federal Ministry of Education and the Universal Basic Education Commission hurriedly put in place the Nigeria Education Sector COVID-19 Response Strategy [14] having 'learn at home' program (LHP) to reduce the slide in learning caused by Covid-19 pandemic as its chief goal. The federating states likewise come up with similar measures. For example, the Lagos state government arrangement is captured thus:

The Lagos State Government, in collaboration with Microsoft Office, represented by ATB Techsoft Solutions, has 
concluded plans to train 18,000 of its Teachers, commencing from Monday, April 27, 2020. The Programme tagged" WorkFrom -Home, Remote Teaching and Learning for Lagos State Secondary School Teachers, aimed at digital training, mentoring, observation, creating and sharing subject-specific content, accessing interactive classes from mobile phones and devices, diagnosing and understanding learning needs and challenges, assigning homework, give feedbacks and auto-grade quizzes/tests remotely and internal stakeholders engagement during the COVID-19 lockdown [15].

However, it is pertinent to examine the sufficiency of the emergence of the e-learning effects instituted by governments on learners, teachers and parents. Aku, et al. [16] in his study entitled "COVID-19 Pandemic and Management of Education System in Nigeria: Impacts of E-Learning Programme Intervention and Google Classroom" concluded that despite the charges that accompany it, the e-learning intervention and Google Classroom can be done effectively during this time of pandemic in educating Nigerian students at all levels. But according to Rosalina, et al. [17] finding, achieving access to internet bandwidth, technological appliances, and students' activities/instructions are embedded with problems. Likewise and in view of the online challenges, virtual learning has been tagged unprogressive since there are interaction barriers as the child or students may not know when to talk as practised in physical class [18]. Hence, the paucity of skills and infrastructure as foundational challenges of the pandemic-inspired online school earlier noted are supposed to be tackled by governments alongside the adoption of e-platforms.

The major consequences of the unresolved foundational problems manifest in the form of the unequal access of school children to remote learning facilities arising mainly from poverty that deprive the poor parents of accessing needed infrastructure, hence creating a disparity in the learning outcomes since children from the rich homes are opportune more than their counterparts from a poor background mostly from the countryside. While this still remains a challenge till date, William, et al. [19] avers that children in remote areas never experienced access to technologies and where it existed was accessed by those with the means.

Furthermore, the impact of the pandemic on teachers and proprietors of private schools is greater when compared with their government employed colleagues, suggesting that the private schools were the worst hit. This stance is validated by a study outcome that shows that the Low-Cost Private Schools in Dominican Republic, Ethiopia, Ghana, Nigeria, Senegal, Uganda and Zambia, a sum of $91 \%$ of schools stated their inability to cater for their teachers' salaries in 2020 [20]. Although the Private school owners also made efforts to assist members through the distribution of palliative, it appears that it is insufficient to keep their staff afloat the economic hardship of the period. It was observed the condition of many of the private school teachers during the heat period of the pandemic pushed many to withdraw a chunk of their savings, borrow, sell assets and aggressively lookout for other avenues of making a living.

In view of the above scenario, it seems logical to posit that the Nigerian governments' educational intervention is not holistic and robust as it is exclusive to public schools, excluding the private learners' citizens out of the equation. As such, this added to the social exclusion crisis, first, between the rich and the poor and second, the heightening of the problem of the parochial policy conception and implementation concerns of the private sector of the economy. Nonetheless, the private tertiary institutions fair better than the public in terms of the exploitation of e-platform learning. Iseolorunkanmi, et al. [21] study reveal that lecturers from the Nigerian private-owned universities keyed into the request for an urgent change to online teaching than their counterparts in the public-owned universities. This can partly be attributed to a better funding and prompt response on the part of the privately-owned Universities.

As part of sustainable solutions to the public school learning environment and funding predicament, Eze, et al. [22] suggest that governments can provide support such as solar-powered educational devices to the disadvantaged and vulnerable students in the rural or local areas in order to cushion the negative effects of the pandemic on education. But more measures appear necessary to minimize the consequences than the one mentioned. Therefore, governments need to take drastic steps to position both the private and public schools for both the current pandemic and the post-pandemic eras.

\section{Economic and Business Institutions}

Data reflecting impacts of the Covid-19 in Nigeria and globally abound in the literature attesting to the fact that it was a devastating experience. For instance [23] maintains that measures such as movement restrictions of people, the decline in the foreign trade and investment and adjustment in the supply chains were targeted at lowering Covid-19 risks but, the outcome ranges from a shortage in supply of protective equipment to contain the spread of Covid-19 to rise in the cost of the basic household while KPMG [24] avers that the state borders across states in Nigeria, the safety and security of workers of needed service providers as they move to different locations during the period of lockdown is worrisome to business owners. In essence, the trade-off of losses is credited to economic and business activities in almost every step taken to flatten the curve of the Covid-19. 
Consequently, the economy recorded the lowest record indices in almost two decades and the World Bank [25] likewise forecasted that the economy is expected to go down by $3.2 \%$, though is to rise again in 2021 by $1.7 \%$. Bishi, et al. [26] studies reveal that Traders experienced low sales, unavailability of cash on hand, and the problem of access to funding and also the business world and its investments were shrouded with uncertainties as investors became cautious of what to invest in and the hazards that may follow [27]. Nevertheless, although with a mixed-feeling, the pandemic has heightened and engendered remote working culture, exploring the digital avenues for carrying out activities, this new state has not just placed non-digital channels on hold [28]. Also, it boosted the ICT business at the same time.

\section{Overview of Governments' Palliative Measures}

Having examined the socio-economic impact of the pandemic on Nigerians as reflected in the sectors, it is essential to juxtapose this with governments' supports measures to appraise the weight of these on both sides. While it is the primary responsibility of the government to ensure the security, social and economic wellbeing of its citizens as enshrined in the constitution (the anchor of the social contract) and in compliance with the International Human Right Law, the extent to which this is carried out, especially amidst a life-threatening situation occasioned by the Covid-19, is an attestation to being responsive and responsible.

Meanwhile, it is noteworthy that the lockdown effects took their toll on not only the private sector but governments and their administrative machinery as well. In this regard, Adelakun, et al. [29] submits that it caused income shortage for the Nigerian government thereby attenuating its assisting capacity to the masses. This, notwithstanding, the Nigerian governments took steps to cushion the economic hardships that accompanied the outbreak of the Coronavirus that are notable and widely publicized. These are:

\section{The Economic Stimulus Package}

This was passed on the 4th of March 2020 by the House of Representatives to support the registration of businesses with the Corporate Affairs Commission under the Company and Allied Matters which is required to float a business outfit. The bill provides for funds from the federation account to bankroll the cost of the registration for the small and medium scale entrepreneurs which seems to have been neglected in the circle of the informal sector despite its significant contribution to the GDP of the Nigerian economy.

Similarly, the Federal Government of Nigeria through the Central Bank (CBN) initiated a N50 billion Targeted Credit
Facility (TCF) as a motivation collection to support families, micro, small and medium enterprises (MSMEs) affected by the COVID-19 pandemic. The stated objectives are to minimize the adverse effects of COVID-19 on families and MSMEs and stimulate credit to MSMEs to enlarge their capacity through equipment upgrade, research and development [30].

As commendable as these efforts are, the outcome or impact appears insignificant on the teeming MSMEs. For instance, it was observed that operators of small businesses in Nigeria got little or no government support in their efforts to survive the economic challenges of the Covid-19 pandemic seen in terms of palliatives to cater for income loss or obtaining loans to continue in their business activities [26]. Implicitly, the acknowledged official business palliatives did not spread across the board of the intended beneficiaries or capture a sizable percentage of their population, making the underlying purpose almost defeated. Hence, governments' efforts could not be argued to be adequate in catering for the business community.

This reality is troublesome because the state, especially the central government, received international assistance which included $\$ 50$ million European Union support funding; the Coalition against Covid-19 (CACOVID), comprising of local big businessmen, $\$ 72$ million; and, the International Monetary Fund (IMF) donation of $\$ 3.4$ billion emergency support fund [7]. Although the support funding clearly indicate global community acknowledgement of the government limited ability to meet the required emergency financial demand, going by her population or demographic data, the performance gap seems wider than expected.

\section{Households Cash Transfers and Food Assistance}

The Nigerian government employs cash transfer and materials - food inclusive - distribution to vulnerable individuals and households as part of bold measures to ease the gravity of the pandemic negative effects on the populace and economy at the same time. First, Twenty thousand Naira (\$10 approximately) was earmarked and disbursed to selected poor households penciled down in the National Social Register (NSR) totaling 2.6 million households (11 million people). Second, the CBN's special loan package of three million Naira was given to a few selected families amongst those that applied without collateral except the provision of guarantors such as community leaders [30]. Unfortunately, the information was not well disseminated to the public making the program almost ineffective. Besides, HRW [31] submits from the conducted survey that the federal and state government cash and food gifts reached only a fraction of families of the populace.

In addition, the Federal Ministry of Humanitarian 
Affairs, Disaster Management and Social Development were mobilized to provide varieties of food stuffs available to vulnerable households across the country. This is expected to reach mostly the remote and countryside dwellers somewhat disconnected from the urban cities. It is a well-thought-out arrangement that would have provided first-hand material palliatives to the rural dwellers if not, according to Dixit, et al. [7] asseveration that it was marred by corruption and lack of accountability. Therefore, it is far from being ascribed as a successful adventure.

As a consequence of the above failure, protest against police brutality tagged 'end-Sars' morphed into a looting spree of warehouses where Covid-19 palliatives are kept in the country, especially in Lagos and Abuja. According to Salau, et al. [32] the carting away of covid-19 palliatives was engineered by hoodlums after setting bonfire at closer junctions and alerted residents to move into the warehouses to cart away the palliatives. Also, the Lagos State Governor Mr. Babajide Sanwo-Olu quipped: "the act of vandalism was regrettable since the items were in the process of repackaging for distribution through groups to transport unions, religious associations, artisans and tradesmen association, market men and women association, people living with disabilities, orphanages and old peoples' homes" [32]. This suggests that citizens are highly disappointed at the government handling of the pandemic situation aside indicating that their endurance of hunger (one of the greatest pains of economic downturn) has gotten to the climax.

\section{Health Sector Funding}

One takeaway benefit believed to have been derived from the Covid-19 pandemic in Nigeria is the greater attention and funding the health sector attracted. Aside from the health workers treated with improved dignity as the frontline workers or soldiers fighting the war against the pandemic, a whooping and unprecedented one hundred billion Naira (\$20 million) was approved for the sector funding [9]. Even though the amount was the first of its kind to be expended at a time in the sector the federal government noted further that it needs about $\$ 330$ million for medical and protective equipment funding [9]. As such, less than ten per cent of the required money to transform the health sector was provided in the heat of the pandemic. This is just the tip of the iceberg that cannot make a visible mark in the industry or the bourgeoning population.

From the above analysis, it is apparent that there is a wide gulf between the government measures to lessen the pandemic adverse effects and the populace socio-economic experience of its benefits. Meanwhile, KPMG, et al. [24] opines that the COVID-19 threat will fade, in the same manner as Ebola, Zika, and Severe Acute Respiratory Syndrome (SARS) viruses have before now but the social and economic impacts would continue to be a challenge long after the virus is conquered. Therefore, a more drastic approach to preventing such enduring effects should be engendered [25-30].

\section{Conclusion and Recommendations}

This study examination of the Covid-19, its social and economic impact alongside government response reveals based on the shreds of evidence that the catastrophic effect of the pandemic on the socio-economic life of Nigerians was not adequately cushioned by the government at all levels especially the central $[31,32]$. The high level of unpreparedness, limited financial capacity coupled with poor administrative structure and corruption are largely responsible for the minimal impact of governments' measures activated alleviate masses suffering [33]. Therefore, the finding affirms the failure of Nigerian governments in upholding the tenets of the social contract as advanced by both Thomas Hobbes and John Locke. To mitigate the current biting pains and set a proactive agenda for a future similar event, the article canvasses the following recommendations [34-36].

First, the Nigerian governments need to scale up their level of preparedness for unforeseen, unexpected or emergencies generally as the world is appearing more fragile and globalized and under the threat of climatechange-orchestrated disasters. Second, the health sector investment should be ramped up for enlarged material and human capacity while all part of the country emergency response strategy marshal plan is explicitly outlined. Third, corruption, which is a national epidemic and bane to national development, should be tackled frontally to pave way for an effective policy and program implementation. Fourth, all sectors should be made to brace-up for the incorporation of technology, which is indispensable in the contemporary time, to enable a remote working environment feasibly when there is physical disruption. And this must be accompanied by strong internet facilities that should be subsidized during an emergency.

\section{References}

1. WHO (2021) Coronavirus disease (COVID-19).

2. Ahmad H, Alisiddqui S, Ahead M, Mishra S (2020) A review of Covid-19 Coronavirus disease -2019, Diagonis, Treatments and Prevention. EJIMO 4(2): 116-125.

3. EiEWG (2020) Nigeria Education Sector COVID-19 Response Strategy in North East.

4. HRW (2020) Nigeria: Protect Most Vulnerable in Covid-19 Response. 
5. World Bank (2020) Global Economic Prospects, January 2021.

6. UNHCR (2020) Socio-economic Impact Assessment of Covid-1 Pandemic among person's of concern in Nigeria.

7. Dixit S, Ogundeji K, Onwujekwe O (2020) How well has Nigeria responded to Covid-19?.

8. Neophitos E (2018) The Theory of Social Contract and Legitimacy Today. Mediterranian Journal of Social Sciences 9(5): 19-28.

9. Yhdego, M (2020) A system Theory of Covid-19 and Religion Contextualized to Asmara Eritrea.

10. Ihekweazu C (2020) Covid-19: Enugu religious leaders urge residents to obey NCDC's regulations.

11. Covid-19-palliatives-in-warehouse/TBIGC

Covid-19: Guide for Governments Working with Religious Leaders to Support Public-Health Measures.

12. Church-Hill A (2021) ICT: A Coping Strategy by Nigerian Churches amidst Covid-19. Research 7(1): 13-18.

13. Anyika V, Anikelechi J, Thobejane T (2021) The Impact of Covid-19 on Nigerian Education System. Journal of Intellectual Disability Diagnosis and Treatment 9(2).

14. Federal ministry of Education (FMoE) (2020) E-Learning Resources.

15. Akoni O (2020) COVID-19 lockdown: Lagos partners Microsoft, ATB on digital training for teachers.

16. Akuh EA (2020) COVID-19 Pandemic and Management of Education System in Nigeria: Impacts of E-Learning Programme Intervention and Google Classroom. International Journal of Innovative Education Research 8(4): 18-123.

17. Rosalina E, Nasrullah N, Elyani E (2020) Teacher's Challenges towards Online Learning in Pandemic Era. Linguistics, Literature and Languages Teaching Journal 10(2): 73-88.

18. Minero, E (2020) 8Strategies to Improve Participation in your Virtual Classroom: Educators share their best synchronous strategies to boost student participation during online learning.

19. William, F (2020) Learning in a Pandemic: Nigeria's Response to Teaching and Learning during the Covid-19 Pandemic. Hewlett Foundation.

20. Alam A, Tiwari P, UNICEF (2021) Implications of Covid-19 for Low-cost Private Schools. Office of Global Insight and Policy.
21. Iseolorunkanmi O, Adebola F, Adebola O, Rotimi E, Nweke C, et al. (2021) Covid-19 Pandemic: Nigerian University Lecturers' Response to Virtual Orientation. Cogent Arts and Humanities 8: 1.

22. Eze U, Selotho M, Onyishi C, Ezeadi C (2021) Impact of Covid-19 Pandemic on Education in Nigeria: Implications for Policy and Practice of e-learning. Library Philosophy and Practice (e-journal).

23. UNCTD (2020) Impact of the Covid-19 Pandemic on Trade and Development, Transitioning to a new Normal.

24. KPMG (2021) Impact of Covid-19 on the Nigerian Consumer and Industrial Market.

25. WB (2020) The World Bank in Nigeria. Overview.

26. Bishi H, Grossman S, Starts M (2021) How Covid-19 affected Lagos Traders, Findings from High Frequency Phone Surveys.

27. Onyekwena C, Ekerue M (2020) Understanding the impact of the Covid-19 outbreak in the Nigeria Economy.

28. KPMG (2020) COVID-19: A Business Impact Series.

29. Adelakun IS (2020) Coronavirus (Covid-19) and Nigerian Education System: Impact Management, Response and way forward. Education Journal 3(4): 88-102.

30. CBN (2020) CBN N100 Billion Credit Support Scheme for the Healthcare Sector.

31. HRW (2021) Between Hunger and the Virus: The Economic Impact of the Covid-19 Pandemic on People Living in Poverty in Lagos, Nigeria.

32. Salau G (2020) Government Condemns raid as residents loot Covid-19 palliatives in warehouse.

33. Andah K, Edeh H, Thurlow J (2020) Impacts of Covid-19 on Food Syste8 and poverty in Nigeria.

34. Federal Ministry of Education (FMoE) (2019) National policy on information and communication technologies in education.

35. Oyewale A, Adebayo 0, Kehinde O (2020) Estimating the Impact of COVID-19 on Small and Medium Scale Enterprises Evidence from Nigeria.

36. UNICEF (2020) Responding to Covid-19. UNICEF Annual Report 2020. 